\title{
AS CIÊNCIAS DA RELIGIÃO, A PSICOLOGIA DA RELIGIÃO E A GESTALT-TERAPIA: EM BUSCA DE DIÁLOGOS
}

\author{
The Sciences of Religion, the Psychology of Religion and the Gestalt-therapy: In Search of Dialogues \\ Las Ciéncias de la Religión, la Psicología de la Religión y la Gestalt-Terapía: En Busca de Diálogos
}

ÊNIo Brito PinTo

\begin{abstract}
Resumo: Depois de se descrever sumariamente como se deu o contato do autor com as ciências da religião, discutem-se algumas fronteiras dessa área acadêmica. É elaborada uma reflexão sumária sobre o campo da psicologia da religião e seus possíveis diálogos com as ciências da religião. Propõe-se a possibilidade de que a abordagem gestáltica possa ser um dos instrumentos da psicologia da religião e das ciências da religião para a compreensão do complexo fenômeno religioso humana.

Palavras-chave: Religião; Ciências da Religião; Psicologia da Religião; Gestalt-terapia.
\end{abstract}

Abstract: After briefly describing how the author's contact with the sciences of religion came about, some frontiers of this academic area are discussed. A brief consideration is elaborated regarding the field of psychology of religion and its possible dialogues with the sciences of religion. The possibility is proposed that the gestaltic approach may be one of the instruments of the psychology of religion and the sciences of religion for the understanding of the complex human religious phenomenon.

Keywords: Religion; Sciences of the Religion; Psychology of the Religion; Gestalt-therapy.

Resumen: Posteriormente a la descripción sumaria de cómo se dio el contacto del autor con las ciencias de la religión, se discuten algunas fronteras entre esa área y el área académica. Es elaborada una reflexión sumaria sobre el campo de la psicología de la religión y sus posibles diálogos con las ciencias de la religión. Se propone como posibilidad el abordaje gestáltico, como uno de los instrumentos de la psicología de la religión y de las ciencias de la religión en la comprensión del complejo fenómeno religioso humano.

Palabras-clave: Religión; Ciencias de la Religión; Psicología de la Religión; Terapia Gestáltica.

"O espírito humano não pode ser apreendido unicamente em termos racionalistas;

muito menos pode ser adequadamente tratado dessa forma. Tentar fazê-lo é um desserviço grave para com a nossa existência e apenas contribui para o sentido de alienação e isolamento que já forma o substrato da vida contemporânea.

(Richard Hycner)

Minha intenção neste artigo é contribuir no incremento do complexo e controverso diálogo entre a academia e a religião. Vou descrever como me aproximei da área das ciências da religião, comentar sobre algumas fronteiras dessa área, delimitar sumariamente a psicologia como uma das ciências da religião e, finalmente, levantar possíveis contribuições da Gestalt-terapia para esse campo.

Quando fiz minha formação em psicologia, na década de 1970, os caminhos acadêmicos na área das humanidades eram um tanto diferentes dos caminhos que percorrem hoje os jovens que se formam nessas ciências. Naquele tempo, lembro-me bem, os professores aconselhavam seus alunos a que, finda a faculdade, buscassem o mercado de trabalho, exercendo as atividades para as quais tinham se formado, colocando-se atentos a fim de perceberem para que caminhos a trajetória profissional impulsionava, para depois, e somente então, aqueles que tivessem pendores acadêmicos procurassem fazer seu mestrado e doutorado. Esses cursos eram, da maneira como aprendi, para profissionais tarimbados, que se aprimorariam ainda mais e, depois, levariam seus conhecimentos e suas experiências profissionais para ensinar os mais jovens.

De lá para cá, muita coisa mudou na área acadêmica, de sorte que hoje os alunos mal acabam a faculdade e já ingressam em cursos de mestrado e doutorado, os quais vão, a pouco e pouco, tornando-se muito mais cursos profissionalizantes que estritamente acadêmicos. Entendo que há aí uma grande influência das chamadas ciências duras, para as quais, em função das peculiaridades desse campo do conhecimento, faz bastante sentido essa rapidez para o ingresso na vida acadêmica. No meu modo de ver, na maioria das ciências humanas há diferenças que não têm sido suficientemente discutidas. $\mathrm{O}$ aprendizado nas ciências humanas é muito mais lento, e, ao contrário das ciências duras, quanto mais velho é o estudante melhor ele aproveita de suas leituras, ou seja, se nas ciências duras um conhecimento pode se tornar obsoleto muito rapidamente, nas humanidades se dá exatamente o contrário, pois tanto melhor será o cientista quanto mais ele 
tiver tempo e amadurecimento para ler, especialmente para ler os clássicos.

Assim, por coerência com minha formação e com essa maneira que tenho para compreender as ciências humanas na academia, depois de bastante tempo de trabalho, depois de uma especialização informal - bem ao gosto da época - em Gestalt-terapia, e de uma especialização formal em psicopedagogia, e levando em conta que eu dava aulas em uma faculdade, entendi que era meu tempo de ingressar no mestrado. Em busca de uma melhor focalização dentre as inúmeras possibilidades acadêmicas que se descortinavam, fui conversar com um acadêmico de larga experiência e pessoa a quem admiro muito, meu primo Ênio Costa Brito. À época, Ênio era coordenador do núcleo das ciências da religião na PUC/SP e, depois de muito conversarmos, me propôs que eu conhecesse a área das ciências da religião e pensasse nelas como uma possibilidade acadêmica para mim. Intrigado, aceitei sua sugestão e comecei a freqüentar como ouvinte algumas aulas do núcleo.

Aos poucos, desvelou-se para mim um terreno muito rico e, ao mesmo tempo, de complicada delimitação. Ciências da religião ou ciência da religião? Ciência da religião ou das religiões? Que área seria aquela? Como minha formação em psicologia e em psicopedagogia poderia ser continuada no campo das ciências da religião? O que se pode estudar nessa área? Qual a diferença que faz para os estudos nessa área a posição religiosa do pesquisador? Por aí afora, foram muitas as questões que brotaram em mim a partir de então, algumas das quais discutirei mais adiante neste artigo.

Naquele momento em que eu resolvia se estudaria as ciências da religião, publiquei meu primeiro livro, sobre o trabalho com a orientação sexual na escola. Com o livro, abriram-se ainda mais as duas áreas nas quais eu atuava profissionalmente, a psicoterapia e a prevenção em sexualidade por meio da orientação sexual na escola. Decidi que o segundo caminho seria convidativo e produtivo para uma interface com as ciências da religião. Entrei formalmente no mestrado, com a proposta de estudar a influência da religião e de seu ideário nas atividades de orientação sexual na escola. De fato, esse foi o tema de meu mestrado. A interface entre a psicoterapia e as ciências da religião eu acabei por explorar em meu doutorado.

Fui orientado no mestrado pelo Prof. Dr. Jung Mo Sung, que, à época, fazia um trabalho estudando as interfaces entre a religião e a economia, um trabalho inspirador para mim. Meu propósito foi seguir um roteiro parecido, trocando a economia pela orientação sexual na escola. Aos poucos, fui imergindo cada vez mais no campo das ciências da religião e compreendendo melhor essa área, com suas poucas respostas e inúmeras perguntas.

Há, anualmente, no Núcleo de Ciências da Religião da PUC/SP, um seminário discente, no qual alguns alunos apresentam seus estudos para serem discutidos pelos professores e alunos do núcleo. Quando fiz o mestrado, participei de um desses debates, apresentando o que tinha pesquisado até então quanto ao meu tema de dissertação. Minha apresentação gerou uma discussão muito empolgada e disputada, propiciada pela observação de um dos professores da casa, para quem a minha dissertação não cabia no campo das ciências da religião. Como a minha dissertação tocava em questões pedagógicas, esse professor defendia que eu deveria desenvolver meus estudos na área da pedagogia, ou na psicologia da educação, mas não nas ciências da religião. Outros professores defenderam a pertinência de meus estudos nas ciências da religião, pois o diferencial de meu estudo era a religião, era a influência da religião no trabalho com a sexualidade na escola, o que caracterizaria a religião como meu tema mais importante de trabalho.

Essa discussão foi tão acalorada e gerou tantas repercussões, que para mim ficou bastante perceptível que a área das ciências da religião ainda não tinha suas fronteiras claramente delimitadas. Hoje, passados já perto de oito anos desse evento, para mim está ainda mais claro que essa área do conhecimento humano ainda precisa se conhecer melhor e, assim, delimitar melhor suas fronteiras. Este artigo é uma pequena contribuição para tanto.

Ao desenvolver meu mestrado, acabei por conhecer e manter bons contatos com religiosos, especialmente padres e religiosas católicos. Por conta desses contatos, passei a conhecer também institutos católicos que ofereciam psicoterapia e trabalhos afins para o clero católico. Tornei-me colaborador de um desses institutos, começando, lentamente, a lidar profissionalmente com maior proximidade com pessoas de vida consagrada. Era um campo novo e interessante que se abria. Comecei dando palestras e coordenando grupos de discussão, geralmente sobre sexualidade humana, tema sempre relevante quando se trata de vida consagrada, para depois passar a receber, em meu consultório, clientes de vida consagrada.

Decorrido algum tempo depois de terminado o mestrado, dediquei-me ao doutorado em ciências da religião, dessa vez estudando as peculiaridades de um processo psicoterapêutico para a clientela composta pelos sacerdotes católicos. Mais uma vez um tema polêmico: seria essa tese pertinente às ciências da religião, ou ela deveria ser desenvolvida no departamento de psicologia? O que caracterizava o elemento central da minha tese? O que ela tinha a ver com as ciências da religião? Estudar religiosos é um tema pertinente às ciências da religião? Essa e outras perguntas semelhantes já me acompanharam desde o início do doutorado. Além de discutir esses temas com meu orientador, o Prof. Dr. João Edênio dos Reis Valle, levantei a questão também com meu professor de epistemologia, o Prof. Dr. Luiz Felipe Pondé. Foram conversas muito estimulantes, as quais, aliadas aos estudos que fiz, me possibilitam discutir agora um pouco mais detalhadamente esse campo tão fértil de conhecimentos que caracteriza as ciências da religião. 


\section{Algumas Fronteiras das Ciências da Religião}

Hoje entendo que o campo das ciências da religião, dada a enorme complexidade e importância de seu foco de estudo, é, por excelência, um campo multidisciplinar, plural, e não simplesmente uma disciplina. É um campo também paradoxal, pois esse campo multidisciplinar e plural é também uma disciplina.

O objeto de estudos das ciências da religião é, no meu modo de ver, a religião. Não é a religiosidade ou as religiões. É a religião, assim mesmo, no singular, genérico, suficientemente vago para caberem nesse termo a religiosidade, a espiritualidade, os mitos, os rituais, a linguagem, as religiões, as pessoas de vida religiosa, a moral e a ética religiosas, o simbolismo religioso, enfim, tudo o que se refira ou que contenha a religião. Para Neville (2001, p. 14), "uma categoria é vaga se ela permite em seu seio coisas que se contradizem; uma categoria é meramente geral se ela requer que as coisas em seu seio sejam mutuamente consistentes". Assim, entendo que o termo religião nas ciências da religião é uma categoria suficientemente vaga, ou seja, abre espaço para a existência simultânea de diferentes coisas em suas fronteiras. Desse modo, o objeto de estudos das ciências da religião interessa e é pertinente às mais variadas ciências, de tal maneira que não me parece possível especificar-se que algum estudo acadêmico seja pertinente somente às ciências da religião. Qualquer estudo, todo estudo que se faça na área acadêmica das ciências da religião é também um estudo pertinente a outra área acadêmica. Nas ciências da religião não há lugar para um tipo de especificidade que encontramos em algumas outras áreas científicas, e esse é um diferencial extremamente positivo para esse campo de estudos, à medida que transforma as ciências da religião no lugar por excelência do diálogo.

É bem verdade que essa peculiaridade das ciências da religião, essa sua pluralidade, coloca esse campo, de certa forma, na contramão dos caminhos acadêmicos atuais, geralmente caminhos de especificidades extremadas. São tantos os conhecimentos que se acumulam em cada área do conhecimento, que, de maneira geral e especialmente nas ciências duras, os profissionais e os cientistas acabam por se tornar especializadíssimos. Como exemplo disso, me lembro de uma observação de um médico urologista, um acadêmico, durante uma conversa informal que tivemos: disse-me ele que são tantos os artigos, são tantas as novas possibilidades, são tantas as atualizações necessárias em sua área de atuação, que ele se via sem possibilidade de estudar outras coisas da própria medicina, o que o obrigava a focar-se tanto no trato geniturinário que ele praticamente esquecia que seus pacientes tinham um corpo mais amplo e complexo. O cientista da religião tem um problema e um risco inversos: seu campo de estudos o obriga a saberes múltiplos, o convida à diversidade, exige o conhecimento e a integração de diversas linguagens.
Essa integração necessária ao cientista da religião não se contenta com uma equipe multiprofissional, como é o caso, por exemplo, da área da saúde: o próprio cientista da religião, todo cientista da religião, precisa ter uma cultura ampla e geral, um conhecimento básico sobre os diálogos das diversas ciências com a religião, ao mesmo tempo em que precisa se aprofundar em sua área específica. O que quero dizer é que, no campo das ciências da religião, não basta ao psicólogo, por exemplo, conhecer psicologia e psicologia da religião, mas ele também terá que ter conhecimentos suficientes de filosofia, teologia, sociologia da religião, antropologia da religião, história da religião, dentre outros saberes relacionados à religião, os quais devem ser integrados numa nova gestalt, necessariamente diferente daquela obtida quando da aproximação teórica baseada especificamente na psicologia. O mesmo raciocínio é válido para quaisquer e todas as subdisciplinas que compõem as ciências da religião. É por isso que Mendonça (2001, p. 149) afirma que "as ciências da religião exigem do pesquisador aquela erudição multidisciplinar que lhe permite usar os vários instrumentos necessários à superação do que simplesmente aparece aos olhos".

Um campo tão amplo e complexo pede uma certa horizontalidade no conhecimento que precisa ser contrabalançada por e integrada a uma certa verticalidade na área de formação principal do cientista; tal tarefa é complicada e difícil, exige bom ritmo, maturidade e humildade na busca incansável da boa forma teórica e metateórica. Essa busca traz a necessidade de um saber que não permita a fragmentação do conhecimento entre as diversas ciências da religião, mas possibilite a integração gerada pela boa confluência entre elas, com realce para uma delas, aquela de origem do cientista. Essa boa confluência, é bom lembrar, é possibilidade, mas não certeza, como aliás, bem lembra Velasco e Bazán (2002, p. 361), para quem:

o estudo da religião e das religiões, que propõe uma reflexão sobre o fenômeno religioso em geral e as características de cada religião no marco do tempo e do espaço (levando em conta tanto as transformações constantes como as mútuas interações) apresenta um grau de complexidade e sofisticação somente abarcável desde a diversidade: de perspectivas, de aproximações, de métodos. Mas, a par disso, tal diversidade, para não diluir-se e se desvirtuar em uma infinidade de enfoques excludentes de camarilhas impermeáveis de especialistas, parece requerer a constituição de uma disciplina de síntese que se sustente em bases metodológicas próprias e estritas.

Em seus estudos sobre a psicomotricidade, JeanClaude Coste (1992, p. 9) classifica essa área do conhecimento como uma "ciência encruzilhada" porque a psicomotricidade "utiliza as aquisições de numerosas ciências constituídas (biologia, psicologia, psicanálise, sociologia e lingüística)". Penso que, de certa maneira, esse epíteto serve também para as ciências da religião, por causa do 
modo como esse campo se constitui; considero também que essa encruzilhada composta pela religião é ainda mais complexa e complicada que a encruzilhada representada pelo corpo na psicomotricidade. Sendo ciência encruzilhada, as ciências da religião são plurais e são ciências do também. Todo estudo em ciências da religião pode ser também um estudo de outra área, de maneira que, como já afirmei anteriormente, não há a possibilidade de uma exclusividade inequívoca das ciências da religião. Por exemplo, minha dissertação de mestrado poderia também ser defendida na área da pedagogia; minha tese de doutorado teria lugar certo também na psicologia da religião.

São várias as disciplinas que dialogam nas ciências da religião. O Núcleo de Ciências da Religião da PUC/SP completou, em 2008, 30 anos de existência; há aproximadamente 10 anos eu freqüento seus bancos, primeiro como aluno e depois como pesquisador. Acompanhei ou soube dos mais diversos estudos, baseados nas mais diversas subdisciplinas: desde o uso do mito do paraíso para o turismo, até a importância da folia de reis em uma pequena comunidade paulista; desde considerações sobre a música sacra até as diversas representações pictóricas de Nossa Senhora; desde a importância da religiosidade na cura de enfermos graves, até o burnout em sacerdotes católicos; desde a influência da religião na moral sexual de um determinado grupo de mulheres, até a atualidade da mística de Meister Eckhart; desde as características da fé pentecostal, até a visão das realidades últimas no budismo, em meio a tantos outros possíveis exemplos.

Então, qual é a especificidade das ciências da religião? O que caracteriza esse campo do conhecimento humano enquanto campo acadêmico? Certamente, como já vimos, é o estudo da religião, mas como é isso? Acredito que as ciências da religião, mais do que ser área do estudo da religião, é área de estudos plurais sobre a religião. É área de ampliação. Embora cada estudo em ciências da religião caiba também em outras áreas acadêmicas, ele pode caber de maneira mais abrangente nas ciências da religião porque ali, e só ali, ele necessariamente será contemplado com contribuições dialogais de outras ciências além daquela específica do pesquisador. Assim, se na sociologia da religião pode-se fazer uma pesquisa levando em conta somente os aspectos sociológicos do fenômeno religioso estudado, nas ciências da religião serão acrescidas a esse olhar contribuições da filosofia, da teologia, da história da religião e de outras áreas, de maneira a que o fenômeno religioso estudado seja compreendido de forma mais ampla e com um grau diferente de profundidade. Isso não quer dizer que um estudo sobre a religião feito na sociologia seja pior ou menos importante do que seria se levado a cabo nas ciências da religião, mas, seguramente, isso quer dizer que ele seria diferente.

Esse é, para mim, um dos paradoxos das ciências da religião: embora essa área se apóie em alguma ciência com identidade isolada, transforma de tal maneira essa ciência que ela deixa de ser a mesma, preservando seus aspectos mais característicos. Um trabalho em ciências da religião fundamentado, por exemplo, na antropologia, será também um trabalho de antropologia, mas terá uma feição com outra especificidade. O paradoxal aqui é que as ciências da religião se tornam, na prática, por causa dessa transformação operada no olhar do pesquisador, a ciência da religião, ou seja, configura-se uma disciplina proveniente do diálogo entre disciplinas. O gestalt-terapeuta compreende isso com base em um dos princípios da psicologia da gestalt: o todo é sempre diferente da soma de suas partes.

Uma das várias ciências que compõem as ciências da religião, uma de suas subdisciplinas, é a psicologia. São inúmeras as contribuições que a psicologia pode dar às ciências da religião, mas me parece que a participação da psicologia nesse campo ainda é tímida, aquém do que poderia ou deveria ser. Em outros termos, entendo que a psicologia pode dar uma contribuição maior e mais direta para esse campo. O caminho para isso é a psicologia da religião, a qual, me parece importante frisar, vai muito além de Jung e Freud. Digo que esse ramo da psicologia está para além desses dois autores porque é mais comum encontramos, nas ciências da religião, trabalhos baseados nesses ramos que em toda a extensa árvore que compõe a psicologia da religião. Estou assim, alertando para o fato de que, embora importantes, a concentração nos trabalhos desses dois autores pode gerar uma tendência de se fazer um reducionismo e acreditar que os trabalhos relevantes em psicologia da religião devam necessariamente passar por eles, o que está longe de ser verdade. Assim, para que possamos continuar essas discussões, agora é necessário que eu delimite, ainda que muito sumariamente, o campo da psicologia da religião, ao mesmo tempo em que me aventuro a tentar traçar mais nitidamente algumas de suas possíveis interfaces com as ciências da religião.

\section{A Psicologia como uma das Ciências da Religião}

Se a psicologia da religião é tímida, às vezes soberba, no campo das ciências da religião, ela é igualmente retraída no campo mais específico da psicologia, a ponto de eu poder afirmar que não conheço nenhuma faculdade de psicologia no Brasil que ofereça essa cadeira como matéria obrigatória ou mesmo opcional para seus alunos. Não posso afirmar que não exista esse curso nas inúmeras graduações em psicologia pelo país afora, mas não tenho dúvidas de que para a maioria das faculdades brasileiras essa ainda é uma área a ser explorada.

Acredito mesmo que a maioria dos psicólogos desconhece essa área de trabalho e de pesquisa na psicologia. É esse desconhecimento que faz Ancona-Lopez (2004, p. 4) comentar que se pode observar entre os psicólogos um certo medo da religião, associado a uma visão deturpada da religião, uma visão que praticamente nega a vitalidade e os processos históricos e psicológicos implicados na 
dinâmica religiosa. O resultado disso, segundo a autora, é uma rejeição à religião e ao campo religioso por parte dos psicólogos, o que, no meu modo de ver, empobrece e limita desnecessariamente o trabalho psicológico e psicoterapêutico.

Eu mesmo, se não tivesse mergulhado no estudo mais amplo do universo religioso e da cosmovisão religiosa propiciado pelas ciências da religião, não conseguiria limpar meu olhar dos matizes do preconceito contra a religião, um colorido que tão demoradamente foi implantado e implantei diante de mim através de anos de aprisionamento em certo psicologismo que teme o religioso. Penso que é preciso uma mudança nesse campo, a religião não pode mais ser vista quase como que um defeito humano, um mecanismo de defesa, uma simples sublimação de algo mais importante, ou mesmo como algo destituído de uma substância própria e completamente explicável com base somente em referenciais não-religiosos. Tampouco a religião pode ser compreendida como apenas uma variável interveniente, quantificável e manipulável em laboratório, um procedimento que sustenta estudos com conclusões que dificilmente poderiam ser aplicados em situações da vida real, as quais são muito mais complexas e aleatórias. A religião é um dado de humanidade! Essa aproximação medrosa e, portanto, preconceituosa de grande parte da psicologia ante a religião não é a única possível e está longe de ser a melhor. Para compreendermos melhor outras possíveis aproximações entre a psicologia e a religião, é preciso delimitar, ainda que muito sucintamente, o campo da psicologia da religião, incluindo seus sucessos e também alguns de seus problemas e desencontros.

Para Massih (2007, p. 6 e ss), a psicologia da religião é, antes de tudo, uma disciplina "não-apologética e nãoconfessional que estuda as experiências religiosas individuais e coletivas e seu reflexo no amadurecimento humano e religioso das pessoas e das comunidades". O objeto de estudo da psicologia da religião, para essa pesquisadora, é a experiência religiosa, de modo que se pretende "entender o fenômeno religioso desde as motivações, experiências, atitudes e dinâmicas afetivas e cognitivas presentes nos comportamentos religiosos".

Mario Aletti (2006, p. 1) entende que a psicologia da religião, por ser "orientada para o funcionamento da psique diante da religião", deve estudar "as estruturas e os processos (as regularidades e as especificidades) da atitude da pessoa religiosa, assumidas como substancialmente estáveis, em nível intrapsíquico, do indivíduo, e comuns e comparáveis em nível interpsíquico, com os indivíduos e com os grupos."

Segundo Valle (1998, p. 51), a psicologia da religião, ao estudar por que e como alguns fenômenos religiosos acontecem e são vivenciados psicologicamente por um sujeito, "indaga sobre a estrutura psicológica que está por trás das formas de vivência e experiência religiosa. (...) A psicologia da religião vê como sua tarefa descrever e 'ex- plicar' psicologicamente a estrutura e a dinâmica do agir religioso do ser humano".

Belzen (2006, p. 24) defende que o propósito da psicologia da religião é usar os instrumentos psicológicos (teorias, conceitos, insights, métodos e técnicas) para analisar e entender a religião. A psicologia da religião deve ser, essencialmente, neutra diante de seu objeto: "ela não pretende promover nem combater a religião, apenas analisá-la e entendê-la.” Dessa forma, ela não é uma psicologia religiosa, da mesma maneira que também a chamada psicologia pastoral não pode ser qualificada como um psicologia da religião.

Assim como a psicologia não é uma ciência una, pois guarda em seu bojo inúmeras controvérsias e visões contraditórias, também na psicologia da religião encontraremos divergências, discussões, diferenças. Valle (1998, p. 261) reconhece na psicologia da religião duas tendências ou posturas básicas: "uma segue uma linha explicativa, empírica, experimental, objetiva, voltado para o consciente e o sociológico; outra prefere pôr-se na direção de uma leitura introspectiva, descritiva, qualitativa, atenta à subjetividade e ao profundo (inconsciente)". Para esse autor, entre essas duas tendências há diversas posições intermediárias, uma espécie de continuum "no qual não faltam tentativas de sintetizar e conciliar as duas linhas básicas”.

Há também divergências quanto ao próprio objeto de estudo da psicologia da religião, especialmente no que diz respeito à abrangência. Por exemplo, Aletti (2006) e Belzen (2006) defendem cada um uma postura nesse quesito. Para Aletti (2006, p. 4), “o psicólogo não estuda o sagrado, nem tampouco estuda a religião, ou a religiosidade, abstratamente (l'homo religiosus)". Segundo esse autor, a aspiração do psicólogo é "estudar o funcionamento psíquico da pessoa em relação à religião que encontra na cultura”. Não interessa para a psicologia a essência, a origem, ou a verdade do conteúdo da religião, mas, como ciência empírica, a psicologia deve ter como objeto um fenômeno concreto, observável: "este homem aqui, determinado, que nesse contexto cultural se confronta com essa religião". Interessa também como esse homem faz esse confronto, "através de quais processos e interações com a totalidade da sua personalidade, com quais conflitos e com quais êxitos". Por acreditar numa postura mais ampla para a psicologia da religião, Belzen (2006, p. 32), que também vê a religiosidade como um dos temas para a psicologia da religião, levanta mais dois pontos importantes que têm que ser levados em conta: "primeiro, a religiosidade deve ser estudada como o resultado de a pessoa estar arraigada na religião num nível cultural, e, segundo, a psicologia não deve se esquecer de tentar dizer algo sobre a religião como um fenômeno cultural também”. Do meu ponto de vista, fazem parte do campo da psicologia da religião, além da espiritualidade e da religião enquanto cultura, compreensões acerca da própria religião, com seus mitos, ritos e símbolos, compreensões 
acerca das instituições religiosas e de seus componentes, sem esquecer ainda que a psicologia da religião tem também o que acrescentar quando se trata de compreender e discutir a moral religiosa.

Um dos mais esclarecedores estudos sobre a maneira como a psicologia se aproxima da religião foi empreendido por Wulff (1997, pp. 634-641). Buscando avaliar as expressões da religiosidade na clínica psicológica e também os trabalhos teóricos e as pesquisas que envolvem o binômio "psicologia e religião”, Wulff (1997) propõe um esquema heurístico bidimensional, no qual traça um gráfico que determina quatro atitudes básicas segundo duas variáveis fundamentais. Nessa proposta, há uma abscissa que vai da literalidade ao simbolismo na visão religiosa, e uma coordenada vertical que vai da inclusão à exclusão da transcendência, de maneira a que se obtenha quatro quadrantes, representantes de posições a partir das quais o psicólogo se relaciona com a religião, a espiritualidade e os conteúdos religiosos em suas pesquisas ou em sua atuação clínica: a afirmação literal (da transcendência); a negação literal; a interpretação redutiva e a interpretação restauradora. Embora eu já tenha comentado sobre esse esquema de Wulff em outro artigo (Pinto, 2005), naquela ocasião eu o fiz com o foco mais centrado na psicoterapia; quero agora abordar esse esclarecedor trabalho de Wulff no que ele pode ser útil para facilitar a compreensão do campo da psicologia da religião e o diálogo dessa área da psicologia com as ciências da religião.

O quadrante da afirmação literal da transcendência é o terreno da psicologia religiosa, próxima de um certo fundamentalismo religioso, na medida que aqui se afirma a existência literal dos objetos religiosos. Por exemplo, são aquelas leituras da Bíblia como se nela encontrássemos verdades literais, as quais prescindiriam de um trabalho hermenêutico. Esse quadrante abriga as posições mais conservadoras nas áreas da religião e da psicologia e propicia que se rejeite todos aqueles e tudo aquilo que questione a validade desse olhar. Segundo Wulff, o que fica esquecido nessa maneira de se lidar com a religião são os fatores históricos e psicológicos que atuam em todas as doutrinas. Wulff completa: como um campo dedicado à clarificação desses fatores, a psicologia da religião naturalmente não é bem recebida entre os religiosos conservadores.

No quadrante da negação literal, encontramos também, como no primeiro, pessoas que entendem que a linguagem religiosa deve ser entendida literalmente, de maneira que aqui também é grande a possibilidade de que se encontrem posturas fundamentalistas com relação ao fenômeno religioso. O que diferencia esta visão da primeira é que aqui há a rejeição de tudo o que se refere à religião, em oposição à aceitação ingênua encontrada no primeiro quadrante. Segundo Wulff, cabem também aqui nesse segundo quadrante aqueles fundamentalistas que rejeitam as outras religiões, mas esse não é exatamente o lugar deles, pois a característica mais importante desse modo de se olhar o fenômeno religioso é a rejeição absoluta de toda reivindicação por verdades reveladas, podendo chegar mesmo ao ponto de se negar até a possibilidade de compreensão dos relatos dos fatos religiosos como metáforas. Dizendo de outra maneira, o que se observa nesse quadrante é uma total dessacralização do universo e um apelo absoluto à racionalidade, além da mesma literalidade na compreensão da linguagem religiosa encontrada no primeiro quadrante, quer dizer, a mesma dificuldade de lidar com os símbolos, como se houvesse outra maneira, que não a simbólica, para que a religiosidade se manifeste. Wulff coloca nesse quadrante grande parte da sociobiologia - que entende a religião como fenômeno que existe para facilitar a adaptação e a seleção natural -, o materialismo médico - o qual defende que os fenômenos religiosos nada mais são do que conseqüências de problemas fisiológicos - e, especificamente na psicologia, o behaviorismo radical, para o qual a religião é unicamente uma agência controladora do comportamento das pessoas (Skinner, 1974). Nesse quadrante a religiosidade é considerada sintoma de patologia ou de imaturidade a ser superada, além de não constituir tema relevante para a psicologia.

Wulff apóia-se em Paul Ricoeur para estudar os quadrantes três e quatro, pois, segundo Wulff, Ricoeur defende que a moderna hermenêutica tem duas tarefas opostas e complementares: por um lado, "redução ou desmistificação", para livrar os símbolos religiosos dos excessos de idolatria e de ilusão; e, por outro lado, "restauração ou relembrança do sentido", para que "o objeto de suspeição possa voltar a ser um objeto de compreensão e de fé.” Essa é uma 'fé racional', que, embora interpretativa, ainda é fé, à medida que busca, através dessa interpretação, "uma segunda ingenuidade".

Para Wulff, na forma mais reducionista da interpretação redutiva encontra-se uma semelhança com a postura do segundo quadrante, pois há uma negação da transcendência na linguagem e na prática religiosa, ou seja, a opção da interpretação redutiva "vê a religião como um fenômeno social ingênuo e ultrapassado e busca perspectivas científicas, consideradas competentes, para interpretar, a partir delas, os conteúdos religiosos" (AnconaLopez, 1999, p. 80). Ainda segundo Ancona-Lopez, "o objetivo implícito (dessa postura) é transformar ou eliminar o campo religioso, reduzindo-o a outras áreas”. Aqui não se desperdiça o símbolo, mas se o seculariza. Um dos mais claros exemplos dessa aproximação reducionista "é representada por Freud e seus seguidores ortodoxos". Para Wulff, Freud "nega claramente a realidade da transcendência" e "reduz os mitos e ritos religiosos à mais mundana realidade".

Ainda com relação ao terceiro quadrante, Wulff diz que uma forma mais humilde e menos ruidosa de aproximação dos fenômenos religiosos pela psicologia pode ser colocada mais próxima do quarto quadrante, embora ainda no terceiro, e pode ser representada por outras 
abordagens psicanalíticas, que não a psicanálise clássica, e até por algumas linhas da psicologia humanista, cujas compreensões da maturidade e da imaturidade religiosas apontam no sentido de "recolocar na religião algum sentido fundamental positivo". Com isso, Wulff quer dizer que se pode observar intenções restaurativas em muitos dos trabalhos colocados no terceiro quadrante, em uma graduação variada.

No quarto quadrante de Wulff há uma compreensão da fé religiosa de uma maneira que permite falar da realidade transcendente para a qual ela aponta. Aqui o domínio da transcendência, como no segundo quadrante, é, de certa forma, colocado como real, mas não no mesmo senso absoluto e literal do segundo quadrante: a busca aqui é pelo simbólico, ou seja, busca-se compreender o sentido simbólico que os fenômenos religiosos têm. Além disso, nessa postura não se reduz as questões religiosas ao seu aspecto cognitivo, mas se busca compreendê-los como ligados à vida como um todo. Não se julgam os objetos e as idéias religiosos, à medida que são encarados como símbolos, o que permite ao psicólogo uma postura mais aberta para os mitos, os ritos e os símbolos religiosos, abrindo caminho para que se aborde a religião "por seus referenciais experienciais: sentimentos profundos e estados internos que vão desde vivências cotidianas a estados transcendentais, sutis ou claramente reconhecidos como míticos" (Ancona-Lopez, 1999, p. 81). Wulff coloca nesse quadrante a psicologia junguiana, a psicologia fenomenológica e o que ele chama de "psicologia interpretativa”.

Wulff afirma, baseado em Flournoy, que uma questão delicada é a que diz respeito à transcendência, pois a psicologia da religião, por princípio, deve excluir o transcendente, no sentido de que ela não pode nunca afirmar ou negar a realidade do objeto religioso, como aliás, já tínhamos visto com Belzen. Com isso, no entanto, a psicologia da religião não tem a intenção de excluir o conhecimento sobre a importância da transcendência para a fé, nem tampouco proibir o estudo sobre as variações na concepção e na observância relacionadas ao transcendente. Wulff acredita que, grosso modo, a experiência mística pode ser considerada essencial para qualquer vivência de fé ou tradição religiosa, independentemente da maneira como possamos rotular ou compreender essa experiência. O que importa é que ela seja levada em conta nos estudos da psicologia da religião.

A maneira como essa relação com a transcendência vai ser levada em conta nos estudos da psicologia da religião tem íntima correspondência com a abordagem que se usa, em psicologia, para fundamentar os estudos. Se seguirmos a tradicional divisão da psicologia em três grandes forças - a psicanálise, o behaviorismo e a linha fenomenológico-existencial - logo perceberemos que as contribuições da área fenomenológico-existencial para a psicologia da religião não são ainda tão desenvolvidas como seria de se desejar. Como conseqüência, também nas ciências da religião encontramos menos contribuições dessa área da psicologia do que seria desejável. Se focarmos ainda mais nosso olhar, veremos que uma das vertentes da psicologia fenomenológico-existencial que ainda tem muito a dialogar com a psicologia da religião e com as ciências da religião é a Gestalt-terapia. Para finalizar essas considerações que ora faço, vou me deter em levantar possíveis contribuições da Gestalt-terapia para esse campo.

\section{A Gestalt-terapia e a Religião}

Dentre as muitas correntes da psicologia, a Gestaltterapia é uma das que têm enorme potencial para funcionar como facilitadora do difícil diálogo entre a ciência e a religião, entre a religião e a ciência. Desafortunadamente, esse potencial não tem sido suficientemente desenvolvido pelos gestalt-terapeutas, como pude comprovar nas inúmeras pesquisas que fiz para o meu doutoramento. Já na tese eu escrevia que nos principais textos da Gestaltterapia, quer seja em livros, quer seja em revistas ou em sites da internet, nacionais e estrangeiros, ainda há menos do que seria desejável que se possa relacionar explícita e diretamente à religião e à espiritualidade. Embora haja aproximações, algumas muito boas, entre a Gestalt-terapia e as religiões orientais, embora haja algumas poucas tentativas de aproximação da abordagem gestáltica com religiões ocidentais, o que encontramos é muito mais uma preocupação com alguns elementos teóricos, alguma postura existencial ou com algum comportamento do que especificamente com a religião no seu sentido mais amplo. O potencial da abordagem gestáltica para o diálogo com a religião precisa ser atualizado.

Dadas as limitações deste artigo, não poderei aqui fundamentar tão longamente como eu gostaria a minha assertiva de que a Gestalt-terapia tem um dos maiores potenciais para funcionar como facilitadora do diálogo entre a academia e a religião. Não me furtarei, no entanto, de desenhar aqui algumas linhas que sustentam essa minha visão. Por ora, dentre as diversas possibilidades, levantarei sete caminhos, sete portas que precisam ser abertas pelos gestalt-terapeutas preocupados com essa potencialidade da abordagem gestáltica. Todas elas derivam de fundamentos da abordagem, são alguns dos vários pontos nos quais me parece que a Gestalt-terapia tem contribuições inovadoras e esclarecedoras para a psicologia da religião e, por conseqüência, para as ciências da religião.

Conceitos centrais na abordagem gestáltica são as noções de contato e de fronteira de contato, a ponto de Perls, Hefferline e Goodman (1997) afirmarem que o objeto de estudo da psicologia é "a operação da fronteira de contato no campo organismo/ambiente” (p. 43. É preciso atenção aqui quanto aos termos, pois contato é palavra corriqueira em nosso idioma, mas tem, em Gestalt-terapia, um significado particular. O conceito de contato define "o intercâmbio entre o indivíduo e o ambiente que o circunda dentro 
de uma visão de totalidade, visto que organismo e meio são um todo indivisível. Contato, desse modo, refere-se aos ciclos de encontros e retiradas no campo organismo/ meio" (Silveira, 2007, p. 59). A fronteira de contato é o ponto no qual se dá a interação entre organismo e meio: "quando dizemos 'fronteira' pensamos em uma 'fronteira entre'; mas a fronteira-de-contato, onde a experiência tem lugar, não separa o organismo e seu ambiente; em vez disso limita o organismo, o contém e protege, ao mesmo tempo que contata o ambiente" (Perls, Hefferline \& Goodman, 1997, p. 43). A fronteira de contato é o ponto no qual indivíduo e religião se contatam e se modificam, é o ponto por excelência para um estudo gestáltico sobre a espiritualidade humana. Isso nos permite inquirir como campo, contato e fronteira de contato são permeados pela espiritualidade. Qual a influência da religião e da espiritualidade no movimento das fronteiras de contato das pessoas? Como pode o gestalt-terapeuta compreender o contato com o sagrado? E as hierofanias? Qual o papel que elas desempenham na formação do campo existencial das pessoas?

O contato se dá em movimentos de enfrentamento e retraimento, o que constitui o ritmo da vida. A pessoa vai ao mundo, entra em contato, mantém-se em contato por algum tempo, para depois retrair-se, voltar-se para si e assimilar o vivido, modificando-se. O enfrentamento é um contato, o retraimento é um contato, um voltado para fora, outro voltado para dentro. Vida é ritmo, pulsação, enfrentamento, retraimento, enfrentamento, retraimento, enfrentamento, retraimento. Se Aletti (2006) entende que o estudo da psicologia da religião deve privilegiar as estruturas e os processos (as regularidades e as especificidades) da atitude da pessoa religiosa, assumidas como substancialmente estáveis, seguramente a abordagem gestáltica, por intermédio dos conceitos de enfrentamento e retraimento enquanto ritmo da vida, dá criativos parâmetros para se estudar de maneira original e profunda as atitudes da pessoa religiosa. O fanatismo, por exemplo, pode ser compreendido como uma falta de ritmo, um contato ininterrupto com o sagrado. Os conceitos de religiosidade intrínseca e extrínseca, de Allport, trazem implícita a questão do ritmo, da mesma maneira que fazem pensar na importante questão das polaridades.

Outro dos pontos importantes da teoria gestáltica, derivado de Jung e ampliado, é o que compreende todo fenômeno psicológico como polar. Para os Polster e Polster (1979, p. 75), essa visão do ser humano como polar não é novidade advinda da Gestalt-terapia: “o que é novo é a perspectiva gestáltica de que cada indivíduo é em si mesmo uma sequência interminável de polaridades. Sempre que um indivíduo reconhece um aspecto de si mesmo, fica implícita a presença de sua antítese ou qualidade polar. Ela fica ali como pano de fundo, dando dimensão à experiência presente". Essa polaridade que fica no fundo é capaz, ainda segundo os Polsters (1979), de surgir como uma figura por direito próprio, se reunir força suficiente. A partir dessa concepção pode-se, por exemplo, buscar uma compreensão acerca de uma polaridade fundamental para a psicologia da religião: a vivência dos aspectos sagrados e dos aspectos profanos do mundo. A partir de um olhar gestáltico, pode-se dizer que sagrado e profano são polares e co-dependentes, verdadeiramente interdependentes. São figura e fundo, fundo e figura, de modo que um contém e define o outro, ao mesmo tempo em que o outro contém e define o um. Sagrado e profano são polaridades presentes na maneira com que o ser humano entende e lida com o mundo, com a história, com o tempo, com o outro, com o sentido e o significado de suas experiências.

Outro conceito da abordagem gestáltica que pode ser útil para o estudo da religião é o conceito de situação inacabada. Se, segundo Valle (1998, p. 261), em função da complexidade de seu objeto, cabe ao psicólogo da religião "analisar a estrutura psíquica da experiência religiosa em seus processos conscientes e inconscientes, em seus elementos emocionais, cognitivos e conativos e em sua dimensão/significado/sentido pessoal, sociogrupal”, um dos instrumentos que a abordagem gestáltica coloca à disposição para essa análise é o conceito de situação inacabada, a gestalt incompleta, extremamente útil para que se possa compreender, por exemplo, a vivência do pecado. Segundo Burow (1985, p. 90), as situações inacabadas têm relação com o princípio da gestalt fechada, isso é, "assuntos não resolvidos (= gestalten abertas) tendem a se fechar em gestalten boas e expressivas. Enquanto estão abertas, as gestalten amarram energias e concentração, prejudicando a ocupação com uma outra tarefa. Só quando estiver fechada, a gestalt poderá se desfazer, dando lugar a outra”. As situações inacabadas prejudicam a capacidade de agirmos no aqui-e-agora porque o que está inacabado no passado exige fechamento no presente para que o ritmo da vida possa ser retomado. Esse fechamento se dá quando a gestalt aberta pode ser fechada, quando a tarefa necessária pode ser executada e a auto-atualização retomada em melhores condições. Desse ponto de vista, pode-se entender a vivência do pecado como uma situação inacabada, uma gestalt que não se fechou e que, pela vivência do remorso ou da culpa, pede completamento; o fechamento dessa situação se dará por meio da reparação ou do perdão, chaves que cicatrizam a ferida, fecham a gestalt aberta, e possibilitam a volta ao ritmo atualizado e dinâmico de formação e destruição de figuras.

Ainda outro conceito útil para que se estude a religião a partir da abordagem gestáltica é o conceito de campo. Se Belzen (2006) defende que a psicologia da religião precisa estudar a religiosidade como o resultado de a pessoa estar arraigada na religião num nível cultural, ele está próximo da concepção gestáltica de campo, embora essa última alcance uma profundidade ainda não experimentada pela psicologia da religião nesse aspecto. Por influência do conceito lewiniano de campo, há em toda a teoria gestáltica uma preocupação em esclarecer as relações entre a 
pessoa e o ambiente na qual ela está imersa, com notável ênfase na compreensão do ser humano por intermedio de uma sensível articulação entre os aspectos biológicos, psicológicos e socioculturais presentes na vida humana. É por isso, por exemplo, que Perls, Hefferline e Goodman (1997, p. 43) afirmam que "não se pode considerar os fatores culturais ou históricos modificando ou complicando condições de uma situação biofísica mais simples, mas como intrínsecos à maneira pela qual todo problema se nos apresenta" (grifos meus). Como afirma Lewin (1973, p. 77), "em toda situação, não podemos deixar de agir de acordo com o campo que percebemos; e nossa percepção se estende a dois aspectos diferentes desse campo. Um tem a ver com fatos, outro com valores". Ambos podem ter a ver com a religião, acrescento eu.

Um outro ponto da teoria gestáltica relevante para a psicologia da religião é a idéia de que o ser humano é um todo, um todo em um campo:

o organismo é um todo. Assim como você pode abstrair a função bioquímica, comportamental, experimental etc., e escolher uma esfera específica de interesse, da mesma maneira você pode abordar o organismo total sob diferentes aspectos, contanto que perceba que qualquer modificação, em qualquer esfera, produz modificações em qualquer outro aspecto correspondente (Perls, 1979, p. 148).

Implícita nessa noção do todo está a sempre presente questão acerca da compreensão do homem como polarizado entre corpo, mente e espírito e imerso em uma cultura, de tal sorte que, quando falamos do ser humano como sendo uma totalidade, devemos nos referir para algo além de um ente apenas biopsicossocial: devemos nos referir a um ente estruturalmente "animobiopsicossocial”, um organismo, integrado por corpo, mente e espírito, o qual habita um lugar e uma cultura e vive em uma época. Não são poucas as possibilidades que essa concepção traz para os estudos sobre a religião, como defende Hycner (1995, p. 88), que, baseado na abordagem gestáltica, entende que devemos tomar em consideração os aspectos espirituais da existência, pois são esses aspectos que propiciam "um contexto que ajuda a tornar a aparente insignificância de nossas ações individuais mais significativas", ou seja, a incorporação da espiritualidade na vida a faz mais significativa. Embora essa significação não dependa totalmente das ações humanas, e ainda que precisemos "agir de forma a 'moldarmos' a matéria-prima que nos é dada", é importante levar-se em conta que o simples fato de estarmos vivos, de respirarmos, de nosso coração pulsar, já é miraculoso e nós somos o lugar desse milagre" (Hycner, 1995, p. 88), O que Hycner (1995) argumenta é que a ausência, na cultura ocidental, de uma certa atitude de assombro e encantamento "representa o empobrecimento de nossa alma", pois "o espírito humano só pode crescer se for nutrido por algo muito maior que ele mesmo. Nossa limitação humana nos abre para o ilimitado" (p. 88).
Para finalizar, quero traçar algumas poucas considerações sobre o diagrama de Wulff e o posicionamento da Gestalt-terapia nesse esquema. No meu modo de ver, a Gestalt-terapia tem lugar no quarto quadrante de Wulff, o da restauração simbólica. Quando Wulff coloca no quarto quadrante a postura hermenêutica que tira dos símbolos religiosos a idolatria e a ilusão, buscando ao mesmo tempo a restauração do símbolo para que ele possa novamente ser uma fonte de significados e de fé, ele fala de um ser humano preso atualmente em uma cultura na qual os símbolos se concretizam e tomam o lugar da realidade, perdendo, assim, sua função mais essencial e se transformando em objeto no lugar de, ou seja, em ídolos. Esse tipo de argumentação e de proposta é claramente afinado à maneira como se lida com os símbolos em Gestaltterapia, e é desse encontro que nasce minha convicção de que a abordagem gestáltica tem lugar no quarto quadrante de Wulff.

Indo ao encontro de Ricoeur quando este trata da desmistificação dos símbolos, Perls, Hefferline e Goodman (1997, pp. 124/127) defendem que esse exagero nos símbolos acaba por colocar o símbolo "em lugar" da natureza, em vez de "junto com" ela. Esses autores alertam para o fato de que a postura de enredamento tão absorvente com os símbolos encontrada no mundo ocidental atual traz perigos, os quais "não são, infelizmente, potenciais, mas manifestos". Dizem Perls, Hefferline e Goodman (1997) que, para se adaptar à vasta acumulação de cultura, o ser humano "é educado em meio a abstrações muito elevadas", de modo que "vive em um mundo de símbolos. Orienta-se simbolicamente como um símbolo em relação a outros símbolos, e manipula simbolicamente outros símbolos", o que, por um lado, proporcionou ao homem "um enorme aumento na amplitude de ação e poder, porque a habilidade de fixar de modo simbólico aquilo em que estávamos totalmente envolvidos permite uma certa indiferença criativa”. Por outro lado, no entanto, aquele lado que Ricoeur trata como o da idolatria, Perls, Hefferline e Goodman (1997) lembram que as estruturas simbólicas (dinheiro, prestígio, a paz pública) acabam por se tornar "objetivo exclusivo de toda atividade, na qual não há nenhuma satisfação animal e pode até não haver nenhuma satisfação pessoal", o que gera "desnorteamento e padrões que nunca podemos alcançar".

Hoje em dia, uma possível reação a esse excesso de simbolismos seria um excesso compensatório de concretudes, uma polarização, igualmente cristalizada, que privilegia o concreto. Nessa polarização cristalizada e reativa, toma-se o prazer pelo prazer, como, por exemplo, na ideologia narcisista que impera no mundo pós-moderno. Em resposta ao símbolo "no lugar de", a relutância em simbolizar, de maneira que hoje as pessoas acabam por ter "um corpo em vez de alma", em reação a uma antiga, mas ainda não ultrapassada, pregação por "uma alma em vez de um corpo". Para Perls, Hefferline e Goodman (1997), a proposta gestáltica é por "um corpo junto de 
uma alma”. Essa proposta implica a possibilidade da integração do símbolo e da concretude da vida, ao invés de um aprisionamento no símbolo ou na concretude, favorecendo a restauração sugerida por Wulff.

Então, como pude demonstrar, ainda de que maneira exígua, por estudar o simbólico e o concreto da vivência humana, a Gestalt-terapia está também instrumentalizada para estudar a religião de uma maneira coerente, criativa, profunda e ampla. A abordagem gestáltica tem como dialogar com a psicologia da religião e as ciências da religião, compondo em encontro que pode iluminar proveitosamente os estudos sobre o existir humano e seu contato com o mistério religioso.

\section{Referências Bibliográficas}

Aletti, M.; Fagani, D. \& Rossi, G. (Org.) (2006). Religione: cultu$r a$, mente e cervello. nuove prospecttive in psicologia della religione. Torino: Centro Scientífico Editore.

Aletti, M. (2006). La Psicologia di fronte a religione e spiritualità nella cultura contemporanea [Acesso em 11/07/2008] . Disponível em: http://www.psicologiadellareligione.it/sipr/ modules/mydownloads/cache/files/4548936135247648325 1718883995248-il_sacro_aletti_per_convegnisti.doc

Ancona-Lopez, M. (1999). Religião e psicologia clínica: quatro atitudes básicas. In M. Massimi \& M. Mahfoud (Orgs). Diante do Mistério: Psicologia e senso religioso (pp.71-86) São Paulo: Loyola.

Ancona-Lopez, M. (2004). A espiritualidade e os psicólogos. Palestra proferida no V Seminário Nacional de Psicologia e senso religioso religião e espiritualidade. PUC-Campinas, Campinas, SP, manuscrito.

Belzen, J. A. (2006). Cultural Psychology of religion: perspectives challenges, possibilities. In M. Aletti, D. Fagani \& G. Rossi (Orgs.). Religione: cultura, mente e cervello. nuove prospecttive in psicologia della religione (pp. 23-57). Torino: Centro Scientífico Editore.

Burow, O-A. \& Scherpp, K-H. (1985). Gestaltpedagogia: um caminho para a escola e a educação. São Paulo: Summus.

Coste, J. C. (1992). A psicomotricidade. Rio de Janeiro: Guanabara Koogan S.A.

Hycner, R. (1995). De pessoa a pessoa: Psicoterapia dialógica. São Paulo: Summus.

Lewin, K. (1973). Problemas de dinâmica de grupo. São Paulo: Cultrix.

Massih, E. (2007). Psicologia da religião: guia de disciplina e caderno de referência de conteúdo (EAD). Batatais: Centro Universitário Claretiano.

Mendonça, A. G. (2001). A cientificidade das ciências da religião, In: F. Teixeira (Org.). A(s) ciência(s) da religião no Brasil: afirmação de uma área acadêmica (pp. 103-150). São Paulo: Paulinas.
Neville, R. C. (2001). Ultimates realities:a volume in a comparative religious ideas project. New York: State University of New York Press.

Perls, F. S. (1979). Escarafunchando Fritz: dentro e fora da lata de lixo. São Paulo: Summus.

Perls, F. S.; Hefferline, R. \& Goodman, P. (1997). Gestalt-terapia. São Paulo: Summus.

Pinto, E. B. (2005). As realidades últimas e a psicoterapia. Anais do XI Encontro Goiano de Gestalt Terapia, Goiânia - GO, (1),.91-98.

Polster, E. \& Polster, M. (1979). Gestalt-terapia integrada. Belo Horizonte: Interlivros.

Silveira, T. M. (2007). Contato (p.59). In: G. D’Acri; P. Lima \& S. Orgler (Orgs.). Dicionário de gestalt-terapia: gestaltês. São Paulo: Summus.

Skinner, B. F. (1974). Ciência e comportamento humano. São Paulo: Edart.

Valle, J. E. R. (1998). Psicologia e experiência religiosa. São Paulo: Loyola.

Velasco, F. D. \& Bazán, F. G. (Orgs) (2002). El estudio de la religión. Madrid: Editorial Trotta.

Wulff, D. (1997). Psychology of religion: classic and contemporary. New York: John Wiley \& Sons.

Ênio Brito Pinto - Psicólogo, Gestalt-terapeuta, Doutor em Ciências da Religião pela PUC-SP, Professor do Instituto de Gestalt de São Paulo; Professor do Curso de Musicoterapia do UniFMU; Professor do Curso de Especialização em Terapia e em Educação Sexual do IPSEX e da Faculdade de Medicina do ABC. E-mail: <eniobrito@uol.com.br>

Recebido em 14.08.08 Primeira Decisão Editorial em 22.09.08 